Raghavendra Mitta*, Sushmitha Duddu, Raghuveer Yadav Pulala, Pradeepkumar Bhupalam, Venkatakirankumar Mandlem and Abbulu Konde

\title{
Mitigative effect of Momordica cymbalaria fruit extract against sodium fluoride induced hepatotoxicity in Wistar male albino rats
}

https://doi.org/10.1515/jbcpp-2019-0362

Received December 31, 2019; accepted July 19, 2020;

published online October 1, 2020

\section{Abstract}

Objectives: The main objective of the present study is to evaluate the mitigative effect of hydroalcoholic extract of Momordica cymbalaria fruits against sodium fluoride (NaF) induced hepatotoxicity.

Methods: In this study, Wistar male albino rats were randomly divided into five groups of six rats each. Group I and II served as normal and toxic controls. Group III as plant control received extract at a dose of $400 \mathrm{mg} / \mathrm{kg} \mathrm{b}$. wt, p.o and Groups IV and V as treatment groups received extract at a dose 200 and $400 \mathrm{mg} / \mathrm{kg}$ b. wt, $p . o$ for 30 days. All groups except Groups I and III received $100 \mathrm{ppm}$ of $\mathrm{NaF}$ through drinking water. After completion of the study, blood collected for the estimation of liver blood serum biomarkers such as aspartate aminotransferases (AST), alanine aminotransferases (ALT), alkaline Phosphatase (ALP), direct and total bilirubin, total protein and albumin. The liver tissue homogenate was for estimation of lipid peroxidation, catalase, and reduced glutathione levels.

Results: The results showed that $\mathrm{NaF}$ intoxication caused elevation of liver blood serum levels and lipid peroxidation; decreased levels of serum total protein, albumin and liver reduced glutathione, and catalase observed. The treatment groups showed decreased elevated serum

*Corresponding author: Dr. Raghavendra Mitta, Associate Professor, Department of Pharmacology, CMR College of Pharmacy, Medchal Road, Kandlakoya (V), Hyderabad, 501401, Telangana State, India, Phone: +91 9948773693, E-mail: mittargv@gmail.com

Sushmitha Duddu and Venkatakirankumar Mandlem, Department of Pharmacology, CMR College of Pharmacy, Hyderabad, Telangana State, India

Raghuveer Yadav Pulala, Department of Biotechnology, IIT-Hyderabad, Sangareddy, Telangana State, India

Pradeepkumar Bhupalam, Department of Pharmacy Practice, RIPER, Anantapur, Andhra Pradesh State, India

Abbulu Konde, Department of Pharmaceutics, CMR College of Pharmacy, Hyderabad, Telangana State, India biomarkers (ALT, AST, and ALP), liver lipid peroxidation and increased serum total protein and albumin, liver reduced glutathione and catalase levels in a dosedependent manner. Histopathological studies also further strongly supported for mitigative effects of the plant.

Conclusions: In conclusion, our findings of the study indicated that $M$. cymbalaria fruits were a potential drug candidate in the treatment of $\mathrm{NaF}$ induced hepatotoxicity.

Keywords: catalase; lipid peroxidation; liver; Momordica cymbalaria; reduced glutathione; sodium fluoride.

\section{Introduction}

Fluoride $\left(\mathrm{F}^{-}\right)$is the element that does not occur in the elemental state in nature because of its high reactivity [1]. It accounts for about $0.3 \mathrm{~g} / \mathrm{kg}$ of the Earth's crust and estimated to be the 13th most abundant element. It exists only in the form of fluorides in several minerals such as fluorspar, cryolite, and fluorapatite [2]. At low concentrations, it is useful for normal mineralization of bone, dentin, and functions of teeth enamel. It is considered as the most productive prophylactic element as well as the treatment agent for dental caries and osteoporosis [3, 4].

Fluorosis is a public health related problem that is endemic all over the globe, including India. At the permissible levels $\left(\mathrm{F}^{-} \leq 1.0 \mathrm{ppm}\right)$, all ingested amount excreted in the urine but when it crosses the permissible levels, it causes dental, skeletal, and non-skeletal fluorosis in both animals as well as in human beings [5, 6]. The primary sources of fluoride intake include drinking water, dental products, food, processed beverages, tea, fluorinated pharmaceuticals, pesticides, and mechanically deboned meat [7, 8]. Referring to a common salt of fluoride as sodium fluoride (NaF), the lethal dose for most adults is estimated to be 5-10 g [9]. At acidic $\mathrm{pH}$, ingested fluorides combine with hydrogen ions to form hydrogen fluoride which was passively entered in the circulation through the passive diffusion process and interferes with the major metabolic pathways [10]. 
Liver is the one the major affected organ for potential fluoride toxicity after the kidney. Earlier studies have clearly shown that intake of high concentration of fluoride in the drinking water causes biochemical changes in the liver by alterations in the synthetic, metabolic, detoxification, excretion, homeostasis, increased lipid peroxidation, disturbed antioxidant defense system, and storage functions may cause hepatotoxicity. Also, histopathological changes reported in the liver after fluoride exposure included necrosis, infiltration of mononuclear cells, swelling of Kupffer cells, extensive vacuolization, hyperemia, ultra structural changes in hepatocytes, and increased apoptosis [11-16].

The plant Momordica cymbalaria, which is a vine of the Momordica genus originated from the Indian states of Andhra Pradesh, Tamil Nadu and Maharashtra, belongs to the Cucurbitaceae family. M. cymbalaria is economical, nutritional-rich, and also contains flavonoids and phenolic compounds as major secondary metabolites. It has been valued for its edible fruits, roots, and leaves as a vegetable [17]. It was already proved for its various medicinal purpose such as cardioprotective effect [18], anti-diabetic, and hypoglycemic activity [19], anti-diarrheal [20], anti-ulcer [21], anti-microbial [22], anti-implantation [23], anti-ovulatory [24], antiangiogenic, anticancer, and anti-tumor [25, 26], and nephroprotective [27] activity. The study aims to see the mitigative effect of hydroalcoholic extract of M. cymbalaria fruits [HAEMC] against NaF induced hepatotoxicity and oxidative stress in male Wistar albino rats.

\section{Materials and methods}

\section{Chemicals}

All chemicals used in the present study were of analytical grade purchased from Sigma-Aldrich Pvt Ltd., Himedia Pvt Ltd., SRL Pvt Ltd., and Research Lab Pvt Ltd., Mumbai, India. Diagnostic kits for the measurement of aspartate aminotransferase (AST), alanine aminotransferases (ALT), alkaline Phosphatase (ALP), direct and total bilirubin, total protein, and albumin purchased from Coral Diagnostics, Mumbai, India.

\section{Collection and authentication of plant material}

The fruits of the plant $M$. cymbalaria collected from the local market of YSR Kadapa, Kadapa district, Andhra Pradesh, India. The plant material authenticated by Dr. Manohar Rao, Taxonomist, Department of Botany, Professor Jayashankar Telangana State Agricultural University, Hyderabad, Telangana state, India.

\section{Preparation of the plant extract}

The freshly collected $M$. cymbalaria fruits washed with distilled water, shade dried, and powdered. The fruit powder was mixed in three different concentrations of 50:50, 30:70, 70:30 (water:ethyl alcohol) and kept aside for one week with occasional stirring. After that, stirred for $20 \mathrm{~min}$ and filtered. The filtrates dried in a rotary evaporator. The suitable extract was selected based on the percentage of yield obtained and stored in the refrigerator at $4^{\circ} \mathrm{C}$ for further studies.

\section{Preliminary phytochemical screening}

The selected hydroalcoholic extract of $M$. cymbalaria fruits was subjected to qualitative phytochemical screening for the identification of phytoconstituents [28].

\section{Experimental animals}

In the experiment, we used adult male Wistar albino rats weighing 200-230 g (8-9 weeks of age). The animals were housed under the conditions of controlled temperature and $12 \mathrm{~h}$ day/night cycle and fed with standard pellet raw chaw and water ad libitum during the study. The experimental protocol used in this study reviewed by the Institutional Animal Ethics Committee (IAEC). IAEC NO: IAEC/1657/ CMRCP/T2/PhD-16/46.

\section{Acute toxicity studies}

Acute toxicity study was performed according to the guidelines of OECD 425.

\section{Experiment protocol}

The rats were randomly divided into five groups of six animals in each group as follows [29]:

Group I (normal control): the rats received drinking water for 30 days.

Group II (toxic control): the rats received $\mathrm{NaF}$ (100 ppm) through drinking water for 30 days.

Group III (HAEMC control): the rats received HAEMC at a dose of $400 \mathrm{mg} / \mathrm{kg}$ p.o for 30 days.

Group IV (HAEMC $200 \mathrm{mg}$ ): the rats received a low dose of HAEMC $200 \mathrm{mg} / \mathrm{kg}$ b. wt, $p . o$ with $\mathrm{NaF}$ (100 ppm) for 30 days.

Group V (HAEMC $400 \mathrm{mg}$ ): the rats received a high dose of HAEMC $400 \mathrm{mg} / \mathrm{kg}$ b. wt, p.o with NaF (100 ppm) for 30 days.

At the end of the study, blood was collected from overnight fasted animals by retro-orbital puncture method. Blood serum used for the estimation of various liver biomarkers such as AST, ALT, ALP, direct and total bilirubin, total protein and albumin. After blood collection, animals sacrificed by cervical dislocation and were cut open to isolate the liver and weighed immediately. Then, the liver was divided into two portions. One portion was stored in $10 \%$ formalin for histopathological study and remaining portion for the estimation of in vivo antioxidant studies. 


\section{Preparation of tissue homogenate}

Tissue was homogenized in chilled $1.15 \%$ potassium chloride using a homogenizer. The homogenate was centrifuged at $800 \mathrm{rpm}$ for $5 \mathrm{~min}$ at $4^{\circ} \mathrm{C}$ (REMI C-24) to separate the molecular debris. The supernatant so obtained was centrifuged at $10,000 \mathrm{rpm}$ for $20 \mathrm{~min}$ at $4{ }^{\circ} \mathrm{C}$ (REMI CM12) to get the post mitochondrial supernatant (PMS), used for estimation of lipid peroxidation, reduced glutathione, and catalase levels.

\section{Biochemical analysis}

Estimation of lipid peroxidation [30]: In this method, $0.5 \mathrm{~mL}$ of PMS taken and added with $0.5 \mathrm{~mL}$ of Tris- $\mathrm{HCl}$ buffer $(0.1 \mathrm{M}, \mathrm{pH} 7.4)$ and incubated at $37^{\circ} \mathrm{C}$ for $2 \mathrm{~h}$ and then $1 \mathrm{~mL}$ of ice cold trichloroacetic acid (10\%) was added and centrifuged at 1,000 rpm for $10 \mathrm{~min}$. From the above, $1 \mathrm{~mL}$ of supernatant was taken and added to $1 \mathrm{~mL}$ of $0.67 \% \mathrm{w} / \mathrm{v}$ thiobarbituric acid $(0.67 \%)$ and the tubes were kept in the boiling water bath for $10 \mathrm{~min}$. One milliliter of distilled water added to the tubes after their removal and brought to room temperature. Absorbance measured at $532 \mathrm{~nm}$ by using a UV-Visible spectrophotometer and the lipid peroxidation is calculated using the following formula:

$$
\frac{3 \times \text { Absorbance }}{50.156 \times(\mathrm{mg} \text { of tissue taken })}=\mu M / m g \text { tissue } \text {. }
$$

Estimation of reduced glutathione (GSH) [31]: In this method, $0.7 \mathrm{~mL}$ of PMS added to $0.75 \mathrm{~mL}$ of sulfosalicylic acid (4\%). The precipitated fraction centrifuged (1200 rpm, $4{ }^{\circ} \mathrm{C}$ for $5 \mathrm{~min}$ ). Half milliliter of supernatant was added to $4.5 \mathrm{~mL}$ of DTNB $(0.1 \mathrm{mM}$ in $0.1 \mathrm{M}$ phosphate buffer, $\mathrm{pH}$ 8.0) solution. Absorbance measured at $412 \mathrm{~nm}$ by using a UV-Visible spectrophotometer. The amount of glutathione expressed as microgram per milligram of tissue and the reduced glutathione level calculated using the following formula:

$$
\frac{3 \times \text { Absorbance of sample }}{13.6 \times(\mathrm{mg} \text { of tissue taken })}=\mu M \text { of } \mathrm{GSH} / \mathrm{mg} \text { tissue } .
$$

Estimation of catalase [32]: In this process, $0.05 \mathrm{~mL}$ of PMS, $1.95 \mathrm{~mL}$ of phosphate buffer $(0.05 \mathrm{M}, \mathrm{pH} 7.0)$ and freshly prepared $1 \mathrm{~mL}$ of $\mathrm{H}_{2} \mathrm{O}_{2}$ (0.019 M, $50 \mathrm{mM}$ phosphate buffer $\mathrm{pH}$ 7.0) were added. The absorbance recorded at $254 \mathrm{~nm}$ three times with 1 min interval against blank. Change in absorbance recorded. The results expressed as $\mu \mathrm{M} / \mathrm{mg}$ of tissue.

\section{Histopathological studies}

The liver samples $(4-5 \mu \mathrm{m})$ were prepared and stained with hematoxylin and eosin dye.

\section{Statistical analysis}

The values were expressed as mean \pm SEM and statistical analysis performed by using one-way analysis of variance (ANOVA) followed by post hoc Dunnett's multiple comparison test using Graph pad Prism 5. Results are considered statistically significant where $\mathrm{p}<0.05$.

\section{Results}

\section{Percentage of yield obtained}

The percentage yield of various proportions of water and ethyl alcohol obtained to be 70:30 (26.7\%), 50:50 (30.3\%), and 30:70 (39\%).

\section{Phytochemical investigation}

The phytochemical constituents of the HAEMC found to be alkaloids, glycosides, steroids, flavonoids, phenols, and tannins as secondary metabolites.

\section{Acute toxicity studies}

The acute toxicity of the HAEMC doesn't show any morbidity and mortality upto the dose of 2,000 mg/ $\mathrm{kg}$ b.wt; this is considered as a cut-off dose. Based on the cut-off dose, 1/10th $(200 \mathrm{mg})$ and $1 / 5$ th $(400 \mathrm{mg})$ of the cut-off doses were selected to study the mitigative effects of HAEMC against NaF induced hepatotoxicity.

\section{Effect on body and liver weights}

The change in body weights in the toxic control group on the 1st and 30th day indicates a significant reduction in the body weights compared to the normal control group. Animals treated with HAEMC showed increased body weight in a dose-dependent manner when compared to the toxic control group. Decreased liver weights were observed in the toxic control group compared to the normal control group and significant recovery was observed in the HAEMC treatment groups in a dose-dependent manner. The body and liver weight variations specified in Table 1.

\section{Effect on liver serum biomarkers level}

Excessive consumption of fluoride increases the blood serum levels of ALT (125.0 \pm 9.85$)$, AST $(99.6 \pm 6.65)$, ALP (73.3 \pm 3.83$)$, direct and total bilirubin $(0.40 \pm 0.04$ and $3.44 \pm 0.30)$ and decreased levels of total protein $(6.40 \pm 0.17)$ and albumin $(2.093 \pm 0.07)$ were observed in toxic control when compared to the normal control $(35.19 \pm 2.40,38.4 \pm 3.09,34.0 \pm 2.43,0.14 \pm 0.01$, $1.25 \pm 0.05,7.36 \pm 0.16$, and $3.925 \pm 0.08$, respectively). After treatment with HAEMC showed at a dose of $200 \mathrm{mg}$ 
Table 1: Effect of HAEMC treatment on body and liver weights against $\mathrm{NaF}$ induced toxicity.

\begin{tabular}{llrrr}
\hline S. & $\begin{array}{l}\text { Name of } \\
\text { No }\end{array}$ & Be group & Body weight, g & $\begin{array}{r}\text { Liver } \\
\text { weight, g }\end{array}$ \\
\cline { 2 - 4 } & 1st day & 30th day & \\
\hline 1. & $\begin{array}{l}\text { Normal } \\
\text { control }\end{array}$ & $221.85 \pm 09.24$ & $245.32 \pm 05.27$ & $8.86 \pm 0.46$ \\
2. & $\begin{array}{l}\text { Toxic } \\
\text { control } \\
\text { 3. }\end{array}$ & $216.66 \pm 16.02$ & $230.00 \pm 15.24$ & $6.54 \pm 0.21$ \\
HAEMC & $209.16 \pm 13.92$ & $249.166 \pm 17.87$ & $8.79 \pm 0.19$ \\
4. & $\begin{array}{l}\text { HAEMC } \\
\text { HAntrol }\end{array}$ & $224.16 \pm 14.22$ & $244.166 \pm 13.32$ & $7.26 \pm 0.24$ \\
5. & HAEMC & $216.667 \pm 15.21$ & $245.833 \pm 14.31$ & $8.75 \pm 0.07$ \\
\hline
\end{tabular}

Values were represented as mean $\pm \mathrm{SEM}$.

HAEMC, Hydroalcoholic extract of $M$. cymbalaria fruits.

$(81.99 \pm 3.64,75.2 \pm 2.80,51.6 \pm 2.69,0.35 \pm 0.03$, $2.43 \pm 0.16,6.66 \pm 0.031$ and $3.215 \pm 0.10)$ and $400 \mathrm{mg}$ $(61.15 \pm 0.94,52.3 \pm 2.95,36.6 \pm 2.41,0.21 \pm 0.01,1.85 \pm 0.09$, $7.94 \pm 0.15$ and $3.822 \pm 0.14$, respectively) dependent recovery from $\mathrm{NaF}$ induced hepatotoxicity. No significant variations were observed in HAEMC control $(37.03 \pm 1.46$, $32.5 \pm 1.78,31.4 \pm 2.01,0.40 \pm 0.04,3.44 \pm 0.30,6.40 \pm 0.17$, and $2.093 \pm 0.07$, respectively) when compared to normal control. All values are specified in Figure 1.

\section{Effect on lipid peroxidation and antioxidant profile of liver}

Effect of HAEMC on the liver lipid peroxidation, reduced glutathione, and catalase levels were specified in Figure 2. There was a significant increase in the lipid peroxidation $(5.24 \pm 0.78)$ and decrease in the levels of reduced glutathione $(4.82 \pm 0.48)$ and catalase $(0.24 \pm 0.06)$ levels observed in toxic control when compared to the normal control $(1.32 \pm 0.35$, $13.2 \pm 0.85$, and $1.18 \pm 0.10)$. Treatment with HAEMC showed significant recovery from lipid peroxidation $(3.17 \pm 0.25$ and $1.61 \pm 0.15)$ and increased levels of reduced glutathione $(8.89 \pm 0.60$ and $13.0 \pm 0.80)$ and catalase $(0.39 \pm 0.10$ and $0.81 \pm 0.04)$ in a dose-dependent manner when compared to the $\mathrm{NaF}$ control. No significant variations observed in the tissue levels of lipid peroxidation $(1.13 \pm 0.91)$ and reduced glutathione $(13.9 \pm 0.46)$ and catalase $(1.35 \pm 0.20)$ in plant control when compared to the normal control.

\section{Histopathological studies}

Histopathological changes of the HAEMC on liver tissue specified in Figure 3. In this, normal control liver tissue showed prominent hepatocytes with preserved cytoplasm, hepatic artery, portal tract, central vein, and normal blood vessels. The toxic control (NaF, $100 \mathrm{ppm}$ ) tissue showed distortion of hepatocytes, central vein and blood vessels, necrosis, and edema. The HAEMC control liver tissue is similar to the normal architecture of the liver tissue. Treatment control-I (HAEMC $200 \mathrm{mg}$ ) showed moderate destruction of hepatocytes, central vein, decreased fibrosis, and edema. Treatment control-II (HAEMC $400 \mathrm{mg}$ ) showed mild damage of hepatocytes, central vein, and decreased fibrosis and edema.

\section{Discussion}

The fluoride acts as the most productive agent for dental caries [33]. At the permissible levels ( $\mathrm{F}-1.0 \mathrm{ppm})$, all ingested amount excretes in the urine. But when it crosses the permissible levels, it causes dental, skeletal, and nonskeletal fluorosis in both animals and human beings [34].

Fluoride exhibits diverse metabolic, structural, and functional toxic effects. The toxic changes depend on the type of cell, duration, and concentration of exposure. It can bind to inhibit the function of $\mathrm{Na}+/ \mathrm{K}+-$-ATPase leading to ATP depletion, alterations in the cell membrane potential, and inactivate function of various key enzymes involved in the glycolysis and the Krebs cycle [35]. At micromolar levels, fluoride inhibits the synthesis and/or secretion of protein, and thus various signaling pathways are involved in the cell multiplication and death, such as mitogenactivated protein kinase, p53, activator protein-1, and nuclear factor kappa pathways. At millimolar concentrations fluoride inhibits various enzymes, including phosphatases [36-38].

Earlier studies discussed the relationship between fluoride and free radical production in various biological systems in natural as well as experimental cases of fluoride toxicity [16]. Antioxidants and chelating agents reduce the stress and/or toxicity against fluoride intoxication [7]. However, long term exposure to vitamins and minerals may not be safe due to their accumulation. Therefore, the study aimed not only mitigation of the fluoride induced toxicity in the liver but also safe, economical, and secure availability in nature. M. cymbalaria fruits are nutritional and unexplored plant material for the treatment of fluoride induced hepatotoxicity and oxidative stress.

Earlier studies clearly reported the variation in the extraction yield depends on the solvent nature and chemical nature of the sample [39]. Based on the percentage of yield obtained, selected 30:70 proportion of hydroalcoholic 


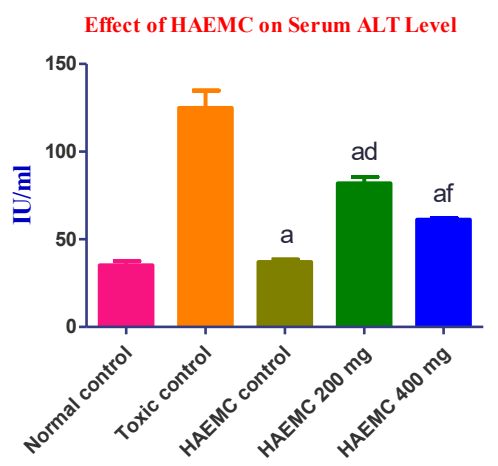

TREATMENT GROUPS

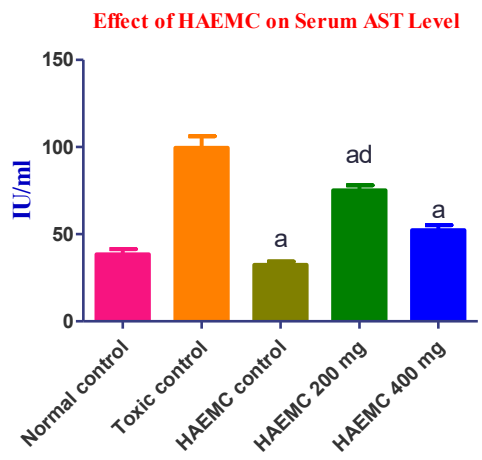

TREATMENT GROUPS

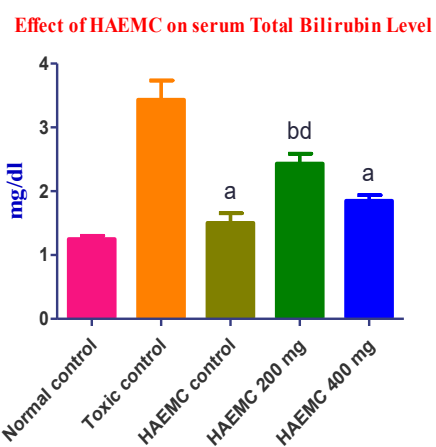

TREATMENT GROUPS

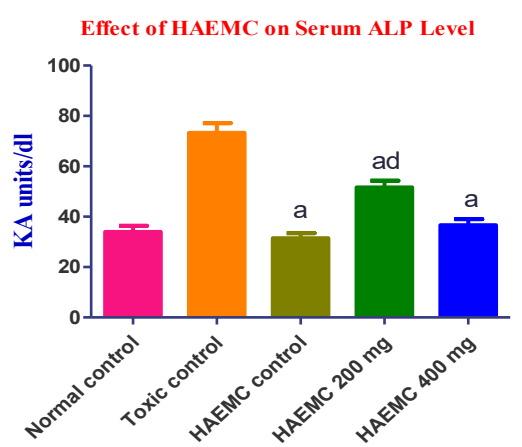

TREATMENT GROUPS

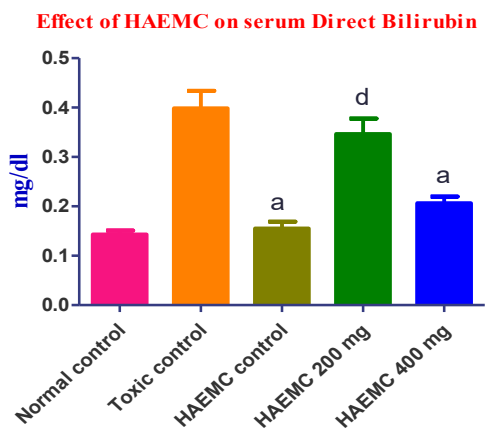

TREATMENT GROUPS

Effect of HAEMC on Serum Albumin Level

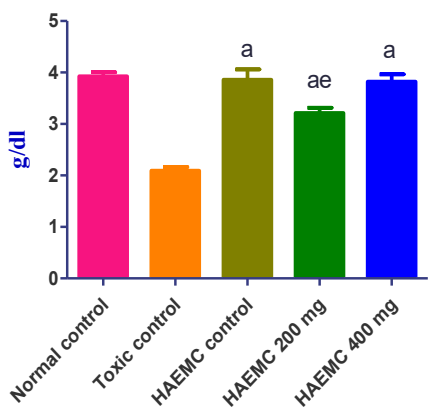

TREATMENT GROUPS

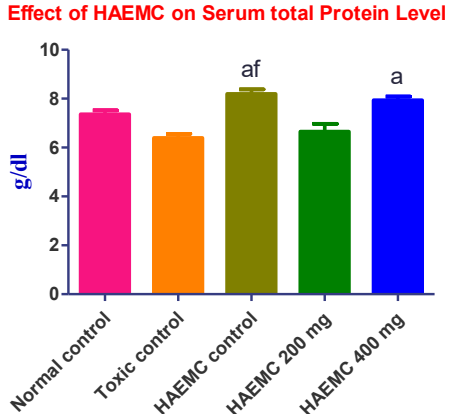

TREATMENT GROUPS
Figure 1: Effect of HAEMC treatment on serum liver profile against $\mathrm{NaF}$ induced toxicity. The values are represented as mean $\pm \mathrm{SEM}$.

Statistical analysis performed using one way ANOVA followed by post hoc Dunnett's multiple comparison test. ${ }^{\mathrm{a}} \mathrm{p}<0.001,{ }^{\mathrm{b}} \mathrm{p}<0.01$, and ${ }^{c} p<0.005$ vs. toxic control; ${ }^{d} p<0.001,{ }^{e} p<0.01$, and ${ }^{f} p<0.005$ vs. normal control. extract is used for further studies. The phytochemical constituents of HAEMC found to be a good source of alkaloids, glycosides, steroids, flavonoids, phenols, and tannins as secondary metabolites. The acute toxicity test of HAEMC showed tolerance at $2000 \mathrm{mg} / \mathrm{kg} \mathrm{b}$. wt, p.o. All the animals in the treatment groups were normal in alertness and 
Effect of HAEMC on Liver Lipid peroxidation Level

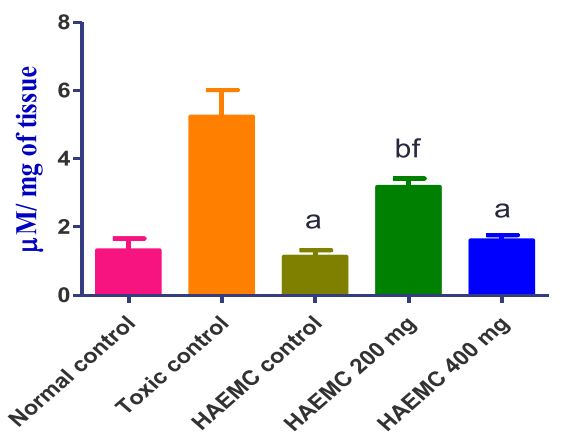

TREATMENT GROUPS

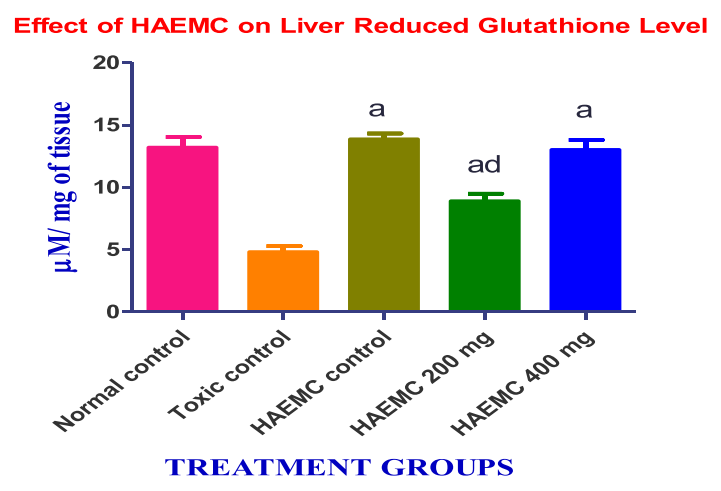

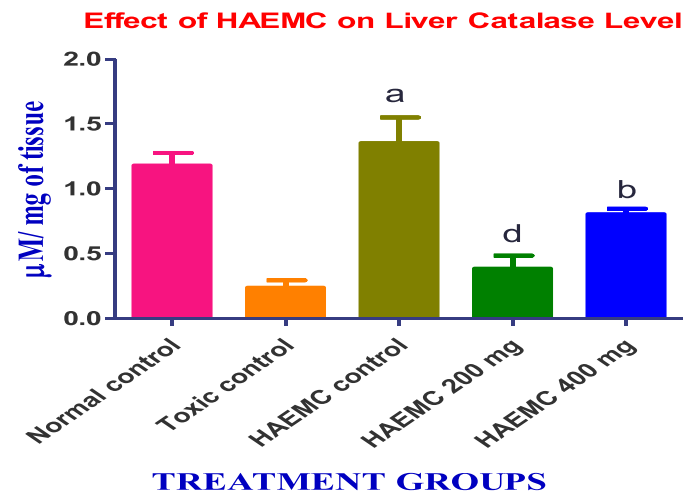

Figure 2: Effect of HAEMC treatment on oxidative stress markers against NaF induced hepatotoxicity. The values are represented as mean \pm SEM. Statistical analysis performed using one way ANOVA followed by post hoc Dunnett's multiple comparison test. ${ }^{a} p<0.001$, ${ }^{b} p<0.01$, and ${ }^{c} p<0.005$ vs. toxic control; ${ }^{d} p<0.001,{ }^{e} p<0.01$, and ${ }^{f} p<0.005$ vs. normal control.

behavior up to $72 \mathrm{~h}$ of post administration. No mortality observed until the completion of the study.

The fluoride exposed rats showed a significant decrease in the body, it might be due to atrophic gastritis and poor absorption in the GIT by disturbed digestibility and decreased appetite was contributed to excessive breakdown of macromolecules causing weight loss. The decreased liver weight observed due to the degeneration of hepatocytes and altered antioxidant systems, which was the primary factor in fluoride toxicity [40]. The improved body and liver weights were found at the end of the study after treatment with HAEMC.

The abnormal increase in the concentration of aminotransferases (AST and ALT) and ALP levels in serum and altered protein metabolism was a clear indication of abnormal function of the hepatic tissue. Previous studies reported that a significant increase in AST, ALT, ALP, direct and total bilirubin levels and decreased levels of total protein and albumin in rats after NaF-intoxication [41, 42]. The increase in the serum bilirubin levels reflects the severity of hepatotoxicity [43]. Data obtained in the present study also revealed that disturbed liver function in toxic control group reflected by increased levels of AST, ALT, ALP, and direct and total bilirubin and decreased levels of total protein and albumin. Treatment with HAEMC at a dose of 200 and $400 \mathrm{mg} / \mathrm{kg}$ b. wt showed normalized serum biomarkers and also increased total protein and albumin levels in a dose-dependent manner. The present results correlate with the findings of the Prakash et al. [44].

Fluoride induces hepatotoxicity by augmenting the free radical formation, which reacts with the polyunsaturated fatty acids to initiate lipid radical chain reaction leading to damage of the cell membrane. It can also reduce the functional capacity of antioxidant system in the hepatocytes cells [45]. The administered HAEMC showed a significant reduction in the lipid peroxidation level and a significant increase in the levels of reduced glutathione and catalase in a dose-dependent manner. These findings have coincided with the results of Perera et al. [12]. Histopathological studies also strongly supported the mitigative effects of HAEMC against fluoride induced hepatotoxicity and oxidative stress. 

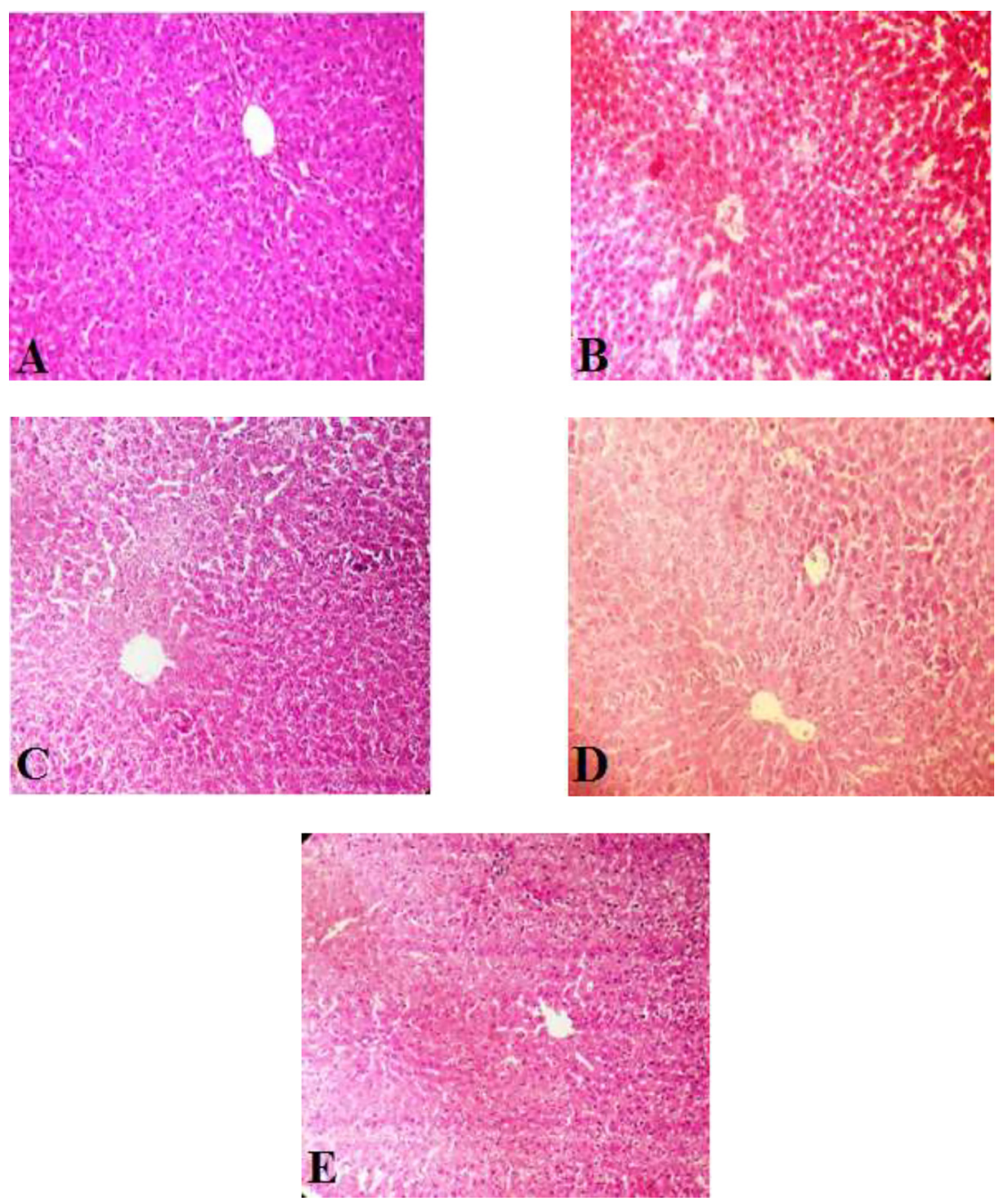

Figure 3: Histopathological studies of liver (magnification 10x).

\section{Conclusion}

In conclusion, the present study has proven that the hydroalcoholic extract of $M$. cymbalaria fruit's effect on $\mathrm{NaF}$ induced hepatotoxicity by decreasing the level of free radical production and also by improving the liver function. We have also concluded that the present results strongly support further application in drug development for the treatment of fluoride toxicity. However, further detailed studies are necessary for a better understanding of changes in the molecular level and exact mechanism involved in the free radical scavenging activity of the plant material.

Acknowledgments: The authors are thankful to Secretary and Correspondent, Mr. Ch. Gopal Reddy, CMR College of pharmacy, Kandlakoya (V), Medchal, Hyderabad, India and special thanks to Mr. Mizoram Varigeti, Assistant Professor, Histologist, IQ City Medical College, Durgapur, West Bengal, India for description of histopathology.
Research funding: There was no funding from any source for this study.

Author contributions: All authors have accepted responsibility for the entire content of this manuscript and approved its submission.

Competing interests: Authors state no conflict of interest. Ethical approval: The experimental protocol used in this study was reviewed by the Institutional Animal Ethics. Committee (IAEC). IAEC NO: IAEC/1657/CMRCP/T2/PhD-16/ 46.

\section{References}

1. Fuge R. Sources of halogens in the environment Influences on human and animal health. Environ Geochem Health 1998;10:51-61.

2. Choubisa SL, Choubisa DK, Joshi SC, Choubisa L. Fluorosis in some tribal villages of Dungapur district of Rajasthan, India. Fluoride 1997;30:223-8.

3. Ghosh A, Mukherjee K, Ghosh SK, Saha B. Sources and toxicity of fluoride in the environment. Res Chem Intermed 2013;39:2881-915. 
4. IPCS. Fluorides. Geneva: World Health Organization; 2002. International Programme on Chemical Safety (2002). Environmental Health Criteria 227.

5. Anfal D, Samir D. Study of fluoride induced haematological alterations and liver oxidative stress in rats. World J Pharm Pharmaceut Sci 2017;6:211-21.

6. DenBeston P, Li W. Chronic fluoride toxicity: dental fluorosis. Monogr Oral Sci 2011;22:81-96.

7. Thangapandiyan S, Miltonprabu S. Molecular mechanism of fluoride induced oxidative stress and its possible reversal by chelation therapy. Res Rev J Toxicol 2013;3:1-11.

8. Ullah R, Zafar MS, Shahani N. Potential fluoride toxicity from oral medicaments: a review. Iran J Basic Med Sci 2017;20:841-8.

9. Whitford GM. Fluoride in dental products: safety considerations. J Dent Res 1987;66:1056-60.

10. Whitford GM, Pashley DH. Fluoride absorption: the influence of gastric acidity. Calcif Tissue Int 1984;36:302-7.

11. Al-Dalhan S, Bhat RS. Protective effect of bee pollen against sodium fluoride induced hepatonephrotoxicity and serum electrolyte changes in rats. Fluoride 2019;52:9-17.

12. Perera T, Ranasinghe S, Alles N, Waduge R. Effect of fluoride on major organs with the different time of exposure in rats. Environ Health Prev Med 2018;23:1-9.

13. Smith GE. The action of fluoride in teeth and bone. Med Hypotheses 1986;19:139-54.

14. Madhusudhan N, Basha PM, Rai P, Ahmed F, Prasad GR. Effect of maternal fluoride exposure on developing CNS of rats: protective role of Aloe vera, Curcuma longa and Ocimum sanctum. Indian J Exp Biol 2010;48:830-6.

15. Reddy RR, Korlakunta NJ, Mitta R. Effect of Arthrospira platensis as a food supplement against sodium fluoride induced intoxication on soft tissues of male Wistar Albino rats. Asian J Pharm Clin Res 2017;10:133-6.

16. Azab AE, Albasha MO, Jbireal JM, Adwas AA. Sodium fluoride induces hepato-renal oxidative stress and pathophysiological changes in experimental animals. Open J Apoptosis 2018;7:1-23.

17. Parvathi S, Kumar VJF. Studies on chemical composition and utilization of the wild edible vegetable Athalakkai (Momordica tuberosa). Plant Foods Hum Nutr 2002;57:215-22.

18. Raju K, Balaraman R, Hariprasad, Kumar MV, Ali A. Cardioprotcetive effect of Momordica cymabalaria Fenzl in rats with isoproterenol-induced myocardial injury. J Clin Diagn Res 2008;2:699-705.

19. Kameswararao B, Kesavulu MM, Apparao C. Evaluation of antidiabetic effect of Momordica cymbalaria fruit in alloxandiabetic rats. Fitoterpia 2003;74:7-13.

20. Swamy BV, Jayaveera K, Reddy KR, Bharathi T. Anti-diarrhoeal activity of Momordica cymbalaria Hook. L. Internet J Nutr Wellness 2005;5:1-6.

21. Dhasan PB, Jegadeesan M, Kavimani S. Antiulcer activity of aqueous extract of fruits of Momordica cymbalaria Hook $f$. in Wistar rats. Pharmacogn Res 2010;2:58-61.

22. Sajjan S, Chetana SH, Paarakh PM, Vedamurthy AB. Antimicrobial activity of Momordica cymbalaria Fenzl aerial parts extracts. Indian J Nat Prod Resour 2010;1:296-300.

23. Koneri R, Saraswati CD, Balaraman R, Ajeesha EA. Antiimplantation activity of the ethanolic root extract of Momordica cymbalaria Fenzl in rats. Indian J Pharmacol 2007;39:90-6.

24. Koneri R, Balaraman R, Saraswati CD. Antiovulatory and abortifacient potential of the ethanolic extract of roots of
Momordica cymbalaria Fenzl in rats. Indian J Pharmacol 2006;38: $111-14$.

25. Koneri R, Nagarathna PKM, Mubasheera MG, Mohan MM. Antiangiogenic and anticancer of saponins of Momordica cymbalaria. Int J Basic Clin Pharmacol 2014;3:70-8.

26. Kaskurthy RL, Koneri RB, Samaddar S. Evaluation of anti-tumor activity of Momordica cymbalaria fenzl. Int J Basic Clin Pharmacol 2015;4:779-86.

27. Pramod K, Devalal RG, Lakshmayya SSR. Nephroprotective and nitric oxide scavenging activity of tubers of Momordica tuberosa in rats. Avicenna J Med Biotechnol (AJMB) 2011;3:87-93.

28. Kumar RS, Venkateswar C, Samuel G, Rao SG. Phytochemical screening of some compounds from plant leaf extracts of Holoptelea integrifolia (Planch.) and Celestrus emarginata (Grah.) used by gondu tribes at Adilabad district, Andhra Pradesh, India. Int J Eng Sci Invent 2013;2:65-70.

29. Vasant RA, Vincent ERC, Karan SS, Narasimhacharya AVRL. Multigrain diet mitigates fluoride induced metabolic toxicity. J Environ Occup Sci 2014;3:25-30.

30. Niehaus WG Jr, Samuelsson B. Formation of malonaldehyde from phospholipid arachidonate during microsomal lipid peroxidation. Eur J Biochem 1968;6:126-30.

31. Jollow DJ, Mitchell JR, Zampaglione NA, Gillette JR. Bromobenzene-induced liver necrosis. Protective role of glutathione and evidence for 3,4-bromobenzene oxide as the hepatotoxic metabolite. Pharmacology 1974;11:151-69.

32. Greenwald AR. Handbook of methods for oxygen radical research. Boca Raton, Florida, United states: CRC Press; 1985:283 p.

33. Onyegeme-okerenta BM, Amadi Band A, Ezeonyilimba VO. The ameliorating potential of Annona muricata on sodium fluorideinduced toxicity on liver and kidney of male wistar rats. J Complement Altern Med Res 2018;6:1-17.

34. Adamek E, Pawlowska-Goral K, Bober K. In vitro and in vivo effects of fluoride ions on enzyme activity. Ann Acad Med Stetin 2005;51: 69-85.

35. Mendoza-Schulz A, Solano-Agama C, Arreola-Mendoza L, ReyesMarquez B, Barbier O, Del Razo LM, et al. The effects of fluoride on cell migration, cell proliferation and cell metabolism in $\mathrm{GH} 4 \mathrm{C} 1$ pituitary tumour cell. Toxicol Lett 2009;190:179-86.

36. Karube H, Nishitai G, Inageda K, Kurosu H, Matsuoka M. NaF activates MAPKs and induces apoptosis in odontoblast-like cells. J Dent Res 2009;88:461-5.

37. Zhang Y, Li W, Chi HS, Chen J, Denbesten PK. JNK/c-Jun signaling pathway mediates the fluoride-induced down-regulation of MMP20 in vitro. Matrix Biol 2007;26:633-41.

38. Zhang M, Wang A, Xia T, He P. Effects of fluoride on DNA damage, $S$ phase cell cycle arrest and expression of NF-KB in primary cultured rat hippocampal neurons. Toxicol Lett 2008;179:1-5.

39. Sasikumar V, Kalaisezhiyen P. Evaluation of free radical scavenging activity of various leaf extracts from Kedrostis foetidissima (Jacq.) Cogn. Food Sci Hum Wellness 2015;4:42-6.

40. Lin CC, Shieh DE, Yen MH. Hepatoprotective effect of the fractions of Ban-zhi-lian on experimental liver injuries in rats. J Ethnophamacol 1997;56:193-200.

41. Xiao-Ying G, Gui-fan S, Ying-chun S. Oxidative stress from fluoride-induced hepatotoxicity in rats. Fluoride 2003;36:25-9.

42. Trivedi MH, Verma RJ, Chinoy NJ. Amelioration by black tea of sodium fluoride-induced effects on DNA, RNA and protein content of liver and kidney on serum transaminase activities in Swiss albino mice. Fluoride 2008;41:61-6. 
43. Basha PM, Madhusudhan N. Pre and post-natal exposure of fluoride induced oxidative macromolecular alternations in developing central nervous system of rat and amelioration by antioxidants. Neurochem Res 2010;35:1017-28.

44. Prakash B, Sabal SK, Verma R, John PJ, Soni I. Sodium fluorideinduced oxidative stress and histological changes in liver of
Swiss albino mice and amelioration by Ocimum sanctum Linn. Asian J Pharm Clin Res 2018;11:195-99.

45. Yildirim S, Ekin S, Huyut Z, Oto G, Combo A, Uyar H, et al. Effect of chronic exposure to sodium fluoride and 7,12-dimethylbenz[A] anthracene on some blood parameters and hepatic, renal and cardiac histopathology in rats. Fluoride 2018;51:278-90. 